\title{
Assessment of the functional capacity and quality of life of Brazilian elderly people living in a community
}

Avaliaçáo da capacidade funcional e qualidade de vida do idoso no Brasil residente em comunidade

Evaluación de la capacidad funcional y la calidad de vida de los ancianos residentes en comunidad en Brasil

Viviane Ferraz Ferreira de Aguiar*iD; Bruna Suely Carmona dos Santos**iD; Driele Caroline Noronha Gomes ${ }^{* * * \text { (ID) }}$

Tereza Cristina Abreu Tavares $* * *$ (iD

\section{Abstract}

Background: The loss of functional capacity (FC) by the elderly compromises autonomy and interferes with quality of life (QL).

Objective: To evaluate the FC score and the QL of elderly people living in a community and to assess the influence of age and gender on FC and QL.

Methodology: Quantitative, exploratory, descriptive research of an applied nature. Sixty-seven elderly people were cared for during the consultations scheduled in a family health unit. A sociodemographic and health data form, basic activities of daily living (BADL), instrumental activities of daily living (IADL) and QL evaluation instruments were used.

Results: For the BADL, there was a lower score only for continence $(54 ; 80.6 \%)$. The majority are independent (63; $94 \%)$ for IADL, mean QL score was $16.1 \pm 1.9$. There was a significant correlation between the variables age and BADL and between IADL and QL. Males obtained a higher mean score $(\mu=26.26)$ for FC, and for QL, there was no significant difference $(p>0.05)$.

Conclusion: Age and gender were associated with FC and QL of the elderly.

Keywords: aged; family health strategy; quality of life; activities of daily living

\section{Resumo}

Enquadramento: A perda da capacidade funcional (CF) pelo idoso compromete a autonomia e interfere na qualidade de vida (QV).

Objetivo: Avaliar a pontuaçáo da CF e a QV dos idosos residentes em comunidade e verificar a influência da idade e sexo com a CF e QV.

Metodologia: Pesquisa quantitativa, exploratória, descritiva e natureza aplicada. Participaram 67 idosos, atendidos durante as consultas programadas em unidade de saúde familiar. Utilizou-se o formulário de dados sociodemográficos e de saúde, instrumentos de avaliação das atividades de vida diária físicas (AVDF), atividades de vida diária instrumentais (AVDI) e QV.

Resultados: Nas AVDF houve um menor registo apenas para a continência $(54 ; 80,6 \%)$. A maioria é independente $(63 ; 94 \%)$ para as AVDI, a pontuaçáo média da QV foi de $16,1 \pm 1,9$. Houve correlação significativa entre as variáveis idade e AVDF e entre AVDI e QV. O sexo masculino obteve maior pontuaçáo média $(\mu=26,26)$ para CF e na QV não há diferença significativa $(p>0,05)$.

Conclusáo: $\mathrm{A}$ idade e sexo estavam associados a $\mathrm{CF}$ e QV do idoso.

Palavras-chave: idosos; estratégia saúde da família; qualidade de vida; atividades quotidianas

*MSc., RN, University Center of Amazónia, School of Nursing, Federal University of Pará, 66053-000, Belém-Pará, Brazil [viviane.ferraz@vahoo.com.br]. (D) https://orcid.org/00000003-3025-1065. Contribution to the article: bibliographical research, statistical treatment and assessment, data analysis, and article writing

**BSc., RN, Family Health Unit of Alto Pindorama, 68721_000, Salinópolis, Pará, Brazil [brunacarmonaenf@hotmail.com]. (1) https://orcid.org/0000-0001-7884-7445. Contribution to the article: bibliographical research, data collection, discussion, and article writing.

****BSc., RN, Special Health Unit, 88798000, Santa Bárbara, Pará, Brazil [drielecarolinego-

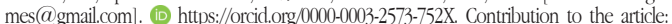
bibliographical research, data collection, discussion, and article writing.

***:BSc., RN, Institute of Health Assistance to Municipal Civil Servants of the Municipality of Belém, 66613-710, Belém, Pará, Brazil [te.tavares1@gmail.com]. (1) https://orcid.org/00000003-1680-5885. Contribution to the article: bibliographical research, data collection, discussion, and article writing.

\section{Resumen}

Marco contextual: La pérdida de la capacidad funcional (CF) por parte de los ancianos compromete la autonomía e interfiere en la calidad de vida $(\mathrm{QV}$, en portugués).

Objetivo: Evaluar la puntuación de la CF y la QV de los ancianos que residen en comunidad y verificar la influencia de la edad y el sexo en la CF y la QV.

Metodología: Investigación cuantitativa, exploratoria, descriptiva y de naturaleza aplicada. Participaron 67 ancianos, atendidos durante las consultas programadas en una unidad de salud familiar. Se utilizaron datos sociodemográficos y de salud, instrumentos de evaluación de las actividades de la vida diaria físicas (AVDF), de las actividades de la vida diaria instrumentales (AVDI) y de la QV.

Resultados: En las AVDF hubo un registro menor solo para la continencia 54 (80,6 \%). La mayoría es independiente $63(94 \%)$ para las AVDI; la puntuación media de la QV fue de 16,1 $\pm 1,9$. Hubo una correlación significativa entre las variables edad y AVDF, y entre AVDI y QV. El sexo masculino tuvo una puntuación media más alta $(\mu=26,26)$ para la $C F$, y en la $Q V$ no hubo diferencias significativas $(p>0,05)$.

Conclusión: La edad y el sexo se asociaron con la CF y la QV de los ancianos.

Palabras clave: anciano; unidad de salud familiar; calidad de vida; actividades cotidianas

Received for publication: 26.02.19

Accepted for publication: 03.06 .19

Série IV - n. ${ }^{\circ} 21$ - ABR./MAI./JUN. 2019 


\section{Introduction}

The change in the epidemiological and demographic profile of the elderly population is reflected on the increased presence of chronic comorbidities responsible for functional and physiological limitations, suffering, and depression (Lobo, Santos, \& Gomes, 2014). It should be pointed out that in Brazilian legislation, in the National Policy on the Elderly and the Statute of the Elderly, a person is deemed to be elderly starting at age 60 .

The changes referred to in terms of pathologies associated with the aging process make the person more vulnerable to situations of frailty, which may bring about the loss of functional capacity (FC), diminishing the necessary skills to perform the basic, instrumental, and advanced activities of daily living, thus requiring the aid of another person (Reis, Marinho, \& Lima, 2016). Research carried out by Freitas, Sarges, Moreira, and Carneiro (2016) justifies that condition, stating that the frail elderly present a lower FC, when compared to pre-frail and non-frail individuals, and, consequently, poor quality of life (QL). Frailty is an important indicator of the physical, cognitive, and social vulnerability of the elderly and its consequences (Jesus, Orlandi, Grazziano, \& Zazzetta, 2017). FC is, therefore, considered to be an important health indicator in the elderly, because its decline results in the loss of autonomy, the risk of dependency, and a deficit in self-care, directly influencing the QL of these individuals (Farías-Antúnez et al., 2014).

The family health unit (FHU) aims to provide an integral service to the family, and one of its strategies is to deliver health care to the elderly, as they present specific health characteristics and require home-based care (Oliveira \& Tavares, 2010). In this respect, the FHU should seek to maintain the functionality of the elderly patient.

For this reason, the researchers felt the need to carry out this study, because the media is continually presenting the current scenario of the senior citizens, so it was perceived the need to develop a study focused on the functional dimension that directly affects the elderly and causes frailty. Thus, research should be conducted on whether the elderly have achieved results for a healthy and active old age, based on their functional maintenance and a suitable QL. The goal, therefore, is to assess the FC score and QL of the elderly living in the community and to assess the influence of age and gender on FC and QL.

\section{Background}

It is an incontrovertible fact that the world's population is aging, and the rate of this aging will be particularly accelerated in the coming decades. In developing countries, such as Brazil, this process will be even more accentuated (Muniz, Goulart, Lazarini, \& Marin, 2017). The change in the epidemiological and demographic profile has been reflected in the attention given to the elderly person, due to the inefficient care provided, without any support for the development of integral care and with the risk of not seeing the factors that may interfere in the homeostasis of that individual. In this context, such changes have been considered the greatest challenge of the $21^{\text {st }}$ century (Lobo et al., 2014), due to the consequences of the aging process as the most significant frailty directly associated with the loss of FC and QL. The presence of functional incapacity is considered multidimensional, as it involves demographic, socioeconomic, behavioral, and health aspects, as well as the type of health service provided to the elderly person. Furthermore, motor, sensory, and cognitive impairments are limiting factors in this reality (Nunes et al., 2017).

Therefore, the loss of FC results in the dependence of the elderly person, because it diminishes the necessary skills to perform the physical, basic, and instrumental activities of daily living, thus requiring the help of third parties to carry them out. This reflects directly on self-care because the autonomy to carry out these activities is impaired (Reis et al., 2016), which in turn directly affects QL.

With the diminished QL, the phase of senility begins more rapidly, disrupting various aspects of the elderly person's life, especially when dealing with autonomy and independence, making self-care more difficult and promoting polypharmacy, which may provoke adverse reactions and drug interactions (Sales, Sales, \& Casotti, 2017). 
In this respect, FHU appears as the main entrance into the Public Health System, seeking to attend to the health particularities of this sector of the population in all the stages of aging, with the purpose of promoting a service of early detection of the risk factors to the elderly person (Silva \& Santos, 2015).

\section{Research question}

What are the FC and QL scores of the elderly person living in the community? Do the age and gender of the elderly person influence the $\mathrm{FC}$ and QL?

\section{Methodology}

This study is quantitative research of an exploratory, descriptive, and applied nature. The study was carried out on a probabilistic sample. The calculation was made with the acceptance of a 95\% confidence level and a sampling error of $5 \%$. After the calculation, the total sample (n) was estimated at 67 elderly persons. The elderly participants in the research were cared for during the consultations scheduled at a FHU, located in the municipality of Belém-Pará, Brazil, in March and April 2018. The criteria for inclusion were age 60 or over, male or female, having been registered in the FHU for at least 6 months, and the criteria applicable for exclusion were elderly with cognitive, auditory, and communicative impairments. The cognitive and auditory assessment was carried out using the Mini-Mental State Examination - MMSE instrument, described as a screening test, and a whispering test. The communicative assessment was carried out during the application of the tests. Candidates with a minimum communication capacity were deemed fit for participation in the research.

The instruments used were a socioeconomic and health data form, the assessment of FC using the Katz Index to evaluate the basic activities of daily living (BADL), the Lawton- Brody Scale for instrumental activities of daily living (IADL), and the WHOQOL-OLD Questionnaire to assess the QL.

The form was created to identify limiting factors that could be related to the current situation of the elderly person. The Katz Index form allows assessing the ability of the individual to carry out his/her activities independently in performing six basic functions: eating, bathing, dressing, toileting, transferring, and continence (Ministério da Saúde, 2006). The Lawton-Brody scale evaluates IADL, such as using the telephone, using a means of transport, shopping, preparing one's meals, cleaning and tidying up the house, taking medication, and handling finances. The score varies from 7 points (total dependence), 8 to 20 points (partial dependence), and 21 points (independence; Melo et al., 2017). The WHOQOL-OLD Questionnaire evaluates the QL of the elderly person and is composed of 24 items divided into six facets, each one of which has four items. The facets may have a score of 4 to 20, that is, the higher the score, the better the QL (Cavalcante, Oliveira, Antunes, \& Carnelozzi, 2018).

The statistical treatment of the variables aimed to assess whether the data converge to any differential, whether there is a trend in the data or not, using the descriptive statistics based on absolute and relative frequencies, in a first phase. In the second phase, statistical tests were applied to infer the results obtained. Pearson's chi-squared non-parametric test was used for the trend/adherence between nominal variables (Ayres, Ayres Júnior, Ayres, \& Santos, 2015), a $p$-value $<0.05$ being adopted as a level of significance, and Student's $t$-test for comparing the means obtained for elderly men and women, at a 95\% level of confidence and 5\% significance.

Therefore, the gathered data were tabulated, processed, and analyzed using descriptive and inferential statistics. For the analysis of the data, computer resources were used. The research was carried out by the ethical principles of resolution no. 466/2012, having been approved by the Ethics and Research Committee of the Metropolitan Faculty of Amazónia (FAMAZ), opinion no. 2.536.031.

\section{Results}

\section{Socioeconomic and health characteristics of the sample}

There were 67 elderly participants in the study, registered in the FHU. The majority were female (44;65.7\%), between 60 and 69 years 
of age $(43 ; 64.2 \%)$, married $(29 ; 43.3 \%)$, had not completed basic education (34; 50.7\%), and had income of up to one minimum salary (39; 67.2\%).

As for their state of health, the majority stated that they did not do any physical activity $(51 ; 76.1 \%)$ and have some chronic illness (46; 68.7\%), namely systemic arterial hypertension $(38 ; 82.6 \%)$ and diabetes mellitus (12;26.1\%). The elderly people's self-perception of their health as good $(29 ; 43.3 \%)$ was predominant, followed by their health being considered regular $(17 ; 25.4 \%)$.

\section{FC and QL of elderly people}

In regard to the BADL performed by the elderly, the responses were divided between yes and no, in which the yes answer predominated, to wit: "personal hygiene" (65; 97\%), "bathing" (64; 95.5\%), "dressing" (64; 95.5\%), "trans- ferring" (64; 95.5\%) and "eating" (64; 95.5\%), indicating a high level of FC. The item "continence" (54; 80.6\%) stands out because it had the lowest positive score.

Regarding the IADL, the majority of the elderly people are independent $(63 ; 94 \%)$, as they scored over 21 points on the Lawton-Brody scale, while only one small group manifested partial dependence $(4 ; 6 \%)$. In the evaluation of QL, in Table 1, the mean score of the general assessment of QL with the WHOQOL-OLD Questionnaire was $16.1 \pm 1.9$ among the elderly, demonstrating that they are satisfied with their QL. In relation to the domains analyzed, the highest mean was obtained in the functional sensory domain $(\mu=17.3)$ and the lowest mean in the autonomy domain $(\mu=14.6)$, which was, therefore, the area with the least degree of satisfaction by the elderly.

Table 1

Mean scores of the WHOQOL-OLD of the elderly patients of the Family Health Unit, in the municipality of Belém, Pará, Brazil

\begin{tabular}{lrrrcc}
\hline Domains & Mean & \multicolumn{1}{c}{$S D$} & VC (\%) & Min & Max \\
\hline Sensory functioning & 17.3 & 2.5 & 14.4 & 11.0 & 20.0 \\
Autonomy & 14.6 & 3.0 & 20.8 & 7.0 & 20.0 \\
Past, present, and future activities & 15.8 & 2.4 & 15.2 & 10.0 & 20.0 \\
Social participation & 16.0 & 2.6 & 16.1 & 8.0 & 20.0 \\
Death and dying & 17.1 & 4.9 & 28.6 & 4.0 & 20.0 \\
Intimacy & 15.9 & 3.8 & 23.8 & 4.0 & 20.0 \\
Total & 16.1 & 1.9 & 11.8 & 11.2 & 20.0 \\
\hline
\end{tabular}

Note. $S D=$ Standard Deviation; $\mathrm{VC}=$ Variation Coefficient; Min = Minimum; Max = Maximum.

\section{Correlation between age, FC, and QL}

As for the correspondence between age, FC, and the QL of the elderly, in Figure 1, there is a weak, but significant correlation between the variables of age and the score on the Lawton-Brody scale, so that the higher the age, the lower the score obtained on the scale, that is, the lower the FC. In addition, it must be noted that there is no significant correlation $(p$ $>0.05$ ) between age and the WHOQOL-OLD score. However, there is a significant correlation between the Lawton-Brody and the WHOQOL-OLD scores, meaning that the higher the WHOQOL-OLD score, the higher the score on the Lawton-Brody scale, that is, the higher the FC, the higher the satisfaction with QL. 

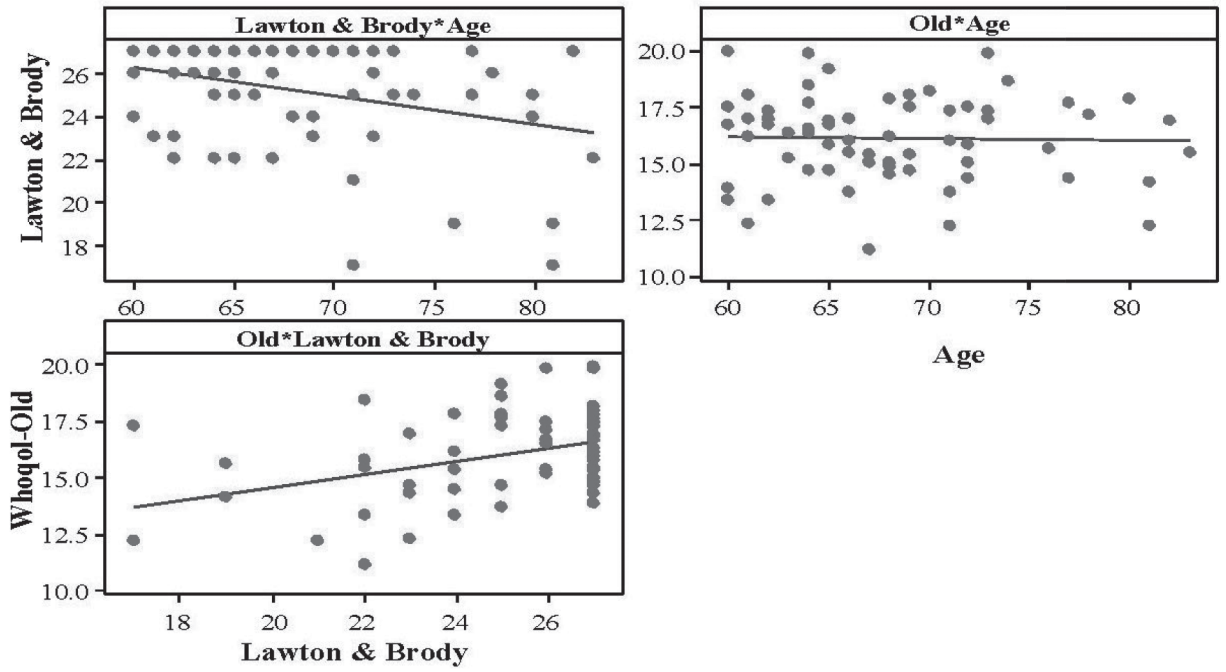

Figure 1. Pearson's correlation test between the variables age, Lawton-Brody score, and WHOQOL-OLD score.

Correlation between gender, FC and, QL of the elderly

The analysis of Table 2 and the mean score on the Lawton-Brody instrument revealed that the elderly males presented a higher mean score $(\mu$
= 26.26), that is, they have a higher FC than women. However, on the WHOQOL-OLD score, there is no significant difference $(p>$ $0.05)$ between the men and women regarding the mean score.

Table 2

Student's t-test for the comparison of mean scores on Lawton-Brody and the WHOQOL-OLD, according to the gender of the elderly

\begin{tabular}{lccc}
\hline Lawton-Brody & Mean & $S D$ & Sig. \\
\hline Female & 24.59 & 2.74 & $0.002^{* * *}$ \\
Male & 26.26 & 1.48 & \\
WHOQOL-OLD & & & \\
Female & 15.84 & 1.91 & $0.099 \mathrm{~ns}$ \\
Male & 16.64 & 1.82 & \\
\hline
\end{tabular}

Note. $S D=$ Standard Deviation; $S i g=$ Significance.

${ }^{* * *}$ Highly Significant Values; ${ }^{\text {ns }}$ Non-Significant Values.

\section{Discussion}

Regarding BADL scores, the results of the research were similar to those of Camacho, Santos, Joaquim, and Abreu (2014), which identified a satisfactory assessment of the FC. Nevertheless, it should be pointed out that the results for the activity continence were below expected among the elderly participants. Therefore, they deserve attention, because incontinence can affect the psychosocial aspects and causes the elderly person to manifest clinical conditions such as sadness, depression, isolation, immobility and, consequently, the lack of desire to carry out daily activities.

The results of the IADL scale were positive for greater functional independence. It is thought 
that this finding may be related to the fact that these elderly persons presented more characteristics which suggest a better FC, as well as their age group, still considered young, and the participants' self-perception of health was considered good. The QL data obtained were generally favorable for the elderly. This result may be related to their living conditions. It was noted that the QL domain most frequently listed by the participants was sensory functioning, and the least chosen was autonomy.

In regard to the first domain, the results show that the aging process is not directly related to the loss of basic functions that compromise daily living, and for Vitorino, Paskulin, and Viana (2012) the sensory functioning (hearing, vision, taste, smell, and touch) allows the elderly person to participate in activities and interact with other people. As for the domain of autonomy, its loss may be influenced by changes in the FC of the elderly person (Lima, Araújo, \& Scattolin, 2016). By assessing whether age and gender influence FC and QL, the research confirmed that result. The age group identified presents the same trends found in other studies, in which the younger elderly persons, from 65 to 69 , present independence for BADL differently from the elderly in the age group of 75 or older, who tend to have a dependence in the BADL and IADL scores (Santos, Silva, \& Silva, 2012). Therefore, older patients tend to have a lower QL because FC is considered a determining factor (Freitas et al., 2016). As age increases, the domains analyzed in the QL tend to decrease (Pereira, Nogueira, \& Silva, 2015).

In the matter of male and female genders, the result found shows that men have a higher FC, which confirms that gender also has a direct influence. These results are in line with those of Guedes, Silva, Banhato, and Mota (2007) regarding the high levels of functional incapacity in women, but there is scientific evidence contrary to that, which emphasizes that women are more independent than men (Santos et al., 2012).

The results obtained allowed identifying the FC and QL of the elderly because the instruments used are internationally validated and deemed to be reliable. However, it should be pointed out that other instruments are necessary to complement the study. It is highlighted that there were some limitations in this research, and therefore, the results cannot be generalized to other researched groups. Furthermore, there were few scientific research projects found that had the same objective as this study, so that comparisons of the current situation of the elderly could be made. It is expected that the survey of results contained in this study will alert to the need to monitor these elderly people in the health service and identify the stratification of risks and the need based on the specific condition of each elderly person.

\section{Conclusion}

It is necessary to understand that the promotion of healthy aging, to ensure autonomy and FC of the elderly person, depends on a suitable QL. Currently, the aging process has generated concerns about the social and epidemiological changes. Therefore, this study is a result of the current reality, because the assessment of FC and QL of the elderly showed that some conditions, such as decreased continence and autonomy, may lead to a progressive loss of FC with time. These results are valuable for immediate intervention because the early identification of the first changes in dependence favors a better quality of life. The correlation between age, FC, and QL allowed identifying that age is one of the determinant factors, and therefore, the stimulation for healthy aging should begin before the elderly person manifests functional changes. The monitoring of the elderly during their old age and the progressive identification of factors that influence their functionality can promote a better QL.

It is suggested that health professionals develop conducts of approximation with the community and use instruments, such as those used in this research, to identify the factors that determine the promotion of priority care, as they are scales that qualified health professionals can apply. It is hoped that the evidence will enable a reflection on the biopsychosocial limitations and the strategies for care to the elderly person.

\section{References}

Ayres, M., Ayres Júnior, M., Ayres, D. L., \& Santos, A. A. (2015). BioEstat 5.4: Aplicaçôes estatísticas nas áreas das ciências biológicas e médicas ( $5^{\mathrm{a}}$ ed.). Belém-Pará, Brasil. Sociedade Civil Mamirauá.

Camacho, A. C., Santos, R. C., Joaquim, F. L., \& Abreu, C. P. (2014). Evaluation of functional capacity in 
care of tissue injuries of adults and elderly patients. Revista de Pesquisa: Cuidado é Fundamental, 6(1), 17-26. doi:10.9789/2175-5361.2014.v6i1.17-26

Cavalcante, D., Oliveira, D., Antunes, M., \& Carnelozzi, A. (2018). Análise da qualidade de vida em idosas praticantes de dança. Revista Interdisciplinar de Promoção da Saúde, 1(1), 23-31. doi:10.17058/ rips.v1i1.11944

Farías-Antúnez, S., Lima, N. P., Bierhals, I. O., Gomes, A. P., Vieira, L. S., \& Tomasi, E. (2014). Incapacidade funcional para atividades básicas e instrumentais da vida diária: Um estudo de base populacional com idosos de Pelotas. Epidemiologia e Serviços de Saúde, 27(2), e2017290. doi:10.5123/s1679-49742018000200005

Freitas, C. V., Sarges, E. S., Moreira, K. E., \& Carneiro, S. R. (2016). Evaluation of frailty, functional capacity and quality of life of the elderly in geriatric outpatient clinic of a university hospital. Revista Brasileira de Geriatria e Gerontologia, 19(1), 119-128. doi:10.1590/1809-9823.2016.14244

Guedes, D. V., Silva, K. C., Banhato, E. F., \& Mota, M.M. (2007). Fatores associados à capacidade funcional de idosos da comunidade. HU Revista, 33(4), 105-111. doi:10.590/1809-2950/13223421042014

Jesus, I. T., Orlandi, A. A., Grazziano, E. S., \& Zazzetta, M. S. (2017). Fragilidade de idosos em vulnerabilidade social. Acta Paulista Enfermagem, 30(6), 614-620. doi:10.1590/1982-0194201700088

Lima, B. M., Araújo, F. A., \& Scattolin, F. A. (2016). Qualidade de vida e independência funcional de idosos frequentadores do clube do idoso do município de Sorocaba. ABCS Health Sciences, 4(3), 168-175. doi:10.7322/abcshs.v41i3.907

Lobo, A. J., Santos, L., \& Gomes, S. (2014). Nível de dependência e qualidade de vida da população idosa. Revista Brasileira de Enfermagem, 67(6), 913-919. doi:10.1590/0034-7167.2014670608

Melo, B. R., Diniz, M. A., Casemiro, F. G., Figueiredo, L. C., Santos-Orlandi, A. A., Haas, V. J., ... Gratão, A. C. (2017). Avaliaçáo cognitiva e funcional de idosos usuários do serviço público de saúde. Escola Anna Nery, 21(4), e20160388. doi:10.1590/2177-9465-ean-2016-0388

Ministério da Saúde. (2006). Envelhecimento e saúde da pessoa idosa (cadernos de atenção básica no 19). Brasília, Brasil: Autor. Retrieved from http://bvsms. saude.gov.br/bvs/publicacoes/evelhecimento_saude_pessoa_idosa.pdf
Muniz, E. C., Goulart, F. C., Lazarini, C. A., \& Marin, M. J. (2017). Análise do uso de medicamentos por idosos usuários de plano de saúde suplementar. Revista Brasileira de Geriatria e Gerontologia, 20(3), 374-386. doi:10.1590/1981-22562017020.160111

Nunes, J. D., Saes, M. O., Nunes, B. P., Siqueira, F. C., Soares, D. C., Fassa, M. E., ... Facchini, L. A. (2017). Indicadores de incapacidade funcional e fatores associados em idosos: Estudo de base populacional em Bagé, Rio Grande do Sul. Epidemiologia e Serviços de Saúde, 26(2), 295-304. doi:10.5123/ s1679-49742017000200007

Oliveira, J. C., \& Tavares, D. M. (2010). Atenção ao idoso na estratégia de saúde da família: Atuação do enfermeiro. Revista da Escola de Enfermagem da USP, 44(3), 774-781. doi:10.1590/S008062342010000300032

Pereira, D. S., Nogueira, J. A., \& Silva, C. A. (2015). Qualidade de vida e situaçáo de saúde de idosos: Um estudo de base populacional no Sertáo Central do Ceará. Revista Brasileira de Geriatria e Gerontologia, 18(4), 893-908. doi:10.1590/1809-9823.2015.14123

Reis, L. A., Marinho, M. S., \& Lima, P. V. (2016). Comprometimento da capacidade funcional: Significados para o idoso e sua família. Revista InterScientia, 2(1),108-121. Recuperado de https://periodicos-. unip-e.br/index.php/interscientia/article/view/62/59

Sales, A. S., Sales, M. G., \& Casotti, C. A. (2017). Perfil farmacoterapêutico e fatores associados à polifarmácia entre idosos de Aiquara. Epidemiologia e Serviços de Saúde, 26(1), 121-132. doi:10.5123/s167949742017000100013

Santos, P. O., Silva, I. S., \& Silva, M. A. (2012). Capacidade funcional do idoso frequentador do programa saúde da família do bairro viveiros do município de Feira de Santana, Bahia. Acta Fisiátrica, 19(4), 233236. doi:10.5935/0104-7795.20120037

Silva, K. M., \& Santos, S. M. (2015). A práxis do enfermeiro da estratégia de saúde da família e o cuidado ao idoso. Revista Texto \& Contexto Enfermagem, 24(1), 105-111. doi:10.1590/0104-07072015000680013

Vitorino, L., Paskulin, L., \& Vianna, L. (2012). Qualidade de vida de idosos em instituiçáo de longa permanência. Revista Latino-Americana De Enfermagem, 20(6), 1186-1195. doi:10.1590/S010411692012000600022 
